\title{
The Study on Trade Policy and Openness of Mongolia: Influences on Trade Flows Between China-Mongolia-Russia (Past and Future)
}

\author{
Fu Qiang, Sodnomdargia Bayanjargal \\ Chongqing University, Chongqing, China
}

\begin{abstract}
This paper aimed to highlight the effects of conflict in Mongolia on trade policy and openness, by estimating the trade flows with neighbor countries (China and Russia). Fourteen years' (2000-2013) data of Mongolian imports and exports were collected and gone through principal component analysis (PCA) and empirical analysis for grouping various trades with China and Russia. The empirical analysis identified the determining factors of Mongolian trade flow and openness with China and Russia. Empirical analysis evidenced that Mongolian trade and openness policy raised bilateral trade between China and Russia, leaving a great influence on economic size. Two main questions represented as empirically tested by each sample country. How did Mongolian trade policy and openness influence trade flows between China and Russia and economic growth of Mongolia? Did Mongolian trade policy and the bilateral trade with China and Russia increase on trade openness? Finally, the study focused on the forecasts from 2016 to 2018 to examine Mongolian trade flows with China and Russia using ordinary least squares method and autoregressive-moving-average (ARMA) model. China-Mongolia-Russia trade flows will continue to dominate during the forecasted period. As shown by the structure of export and import, goods with China and Russia influenced the mutual trade amount. Moreover, China and Russia traded to continue with Mongolia for goods in long run. Trade policy and openness, the major contributor in Mongolian economy, are significantly playing roles in trade and economy.
\end{abstract}

Keywords: trade policy, openness, neighbour countries, influence

\section{Introduction}

Due to the increasing and development of trade and economy, all countries take different trade policies at different time from each country (International Trade Policy/Baidu, 2012). Mongolian trade policy has an open trade policy: tariff rate is relatively lower and beneficial relationship for export and import to international trade. The conception of trade policy and openness is very important for every country. Mongolia is located between two big countries, therefore Mongolia has to explore past and future tendency of economic trade appearance through two neighbor countries to hold foreign trade with other countries.

Fu Qiang, professor, College of Economics and Business Administration, Chongqing University, Chongqing, China.

Sodnomdargia Bayanjargal, Ph.D. student, College of Economics and Business Administration, Chongqing University, Chongqing, China.

Correspondence concerning this article should be addressed to Sodnomdargia Bayanjargal, College of Economics and Business Administration, Chongqing University, campus B, room \#322, Shapingba District, Chongqing, China. 
Arvind, Jagdish, and Srinivasan (1998); Nayyra, Fu, and Sundas (2014); Oyunbadam, Kishor, and Yapa (2014); Antoine and Andreas (2006); and Munkh-Erdene (2014) showed that trade openness was positively related to economic growth, financial development, and trade size.

From May 1, 1997 to July 1, 1999, tariffs were eliminated across the board only to be re-imposed at a uniform level of five percent in 1999 (then increased to seven percent in January 2001). Since 2002, Mongolia has applied an across-the-board most favored nation (MFN) tariff of five percent, with few exceptions (Ministry of Foreign Affairs and Trade \& United Nations Development Program in Mongolia, 2008).

By becoming the member of the WTO in 1997, Mongolia has proven to support the concept of multilateral trading system and the trends of global economic development. Mongolia has continuously been encouraging multilateral trading system. Mongolia has, in the past, pursued a more open and liberal trade policy, eliminating step-by-step trade barriers by cutting high tariffs and reducing non-tariff measures. All tariff lines are bound; the average bound rate was $18.4 \%$ in 2004 . Bound rates are higher than applied MFN rates for most lines, thereby, according to Mongolian considerable latitude to raise its tariffs within existing bindings. Due to a relatively uniform tariff structure, which simplifies customs procedures, reduces market distortions, and enhances transparency, there is no tariff escalation, and there are no tariff peaks. Some agricultural products ( $0.3 \%$ of total tariff lines) are protected by a seasonal rate of $15 \%$. Mongolia has not used any anti-dumping, countervailing, or safeguard measures (World Trade Organization, 2005).

The representative domain for this study is Mongolian foreign trade chosen per neighbor countries as prescribed by the categorization "China and Russia” during 2000-2013.

According to Robin (2012) and Muhammad, Irfan, and Sadaf (2014), this paper explained the result of principal component analysis. Principal component analysis (PCA) was applied to the estimate of Mongolian trade goods, total trade volume of imports versus export with China and Russia. China and Russia seem to be the biggest export and import countries with Mongolia. PCA further showed the higher percentage of Mongolian products being exported or imported in bilateral trade with neighbor countries. Separating to estimate, Mongolian mainly goods traded the amount volume for export and import to China and Russia and aimed to show China or Russia is main export and import country of Mongolia and what products accounted high percent of Mongolia are being exported and imported on bilateral trade with China and Russia.

Main export commodities of Mongolia have included meat, raw hides and leathers, wool, cashmere, and mining products. Main import goods have included the petroleum, food preparation products, vegetables, wine, beer food commodities, fruits, household materials, motor cars, and other motor vehicles for the transport persons with foreign countries.

Secondly, the study runs the empirical evidence that is using seven variables by regression results, Mongolian trade policy and openness aimed to study the influence of bilateral trade between China and Russia during 2000-2013. Two main questions represented as empirically tested by each sample country. How did Mongolian trade policy and openness influence trade flows between China and Russia and economic growth of Mongolia? Did Mongolian trade policy and the bilateral trade with China and Russia increase trade openness? All variables included GDP, population, trade openness, foreign direct investment, export and import tax, and total trade with China and Russia.

Finally, this paper focused on the forecasts from 2016 to 2018 to examine Mongolia's trade flows with China and Russia using ordinary least squares (OLS) method and ARMA terms. Models with ARMA terms are widely used in forecasting. In addition, the study aimed at analyzing whether Mongolia's trade flows with 
China and Russia will continue to increase in future. Besides, the study also forecasted the short term bilateral trade with China and Russia from 2016 to 2018. This paper used the Eviews online tutorials (basic forecasting) of IHS Global Inc (n.d.).

The structure of this paper is as follows. Section II introduces the literature review. Section III presents research methods. Section IV examines research results. The paper finally provides the discussion of trade policy and overview trade with China and Russia and ends with some concluding remarks.

\section{Literature Review}

Many papers regarding bilateral trade between China-Mongolia-Russia have showed China and Russia may play a significant role in Mongolian foreign trade. In this section, the paper shows the literature reviews related of trade with China \& Russia and focused about Mongolian main sectors' trade. Because this paper focuses that Russia-China-Mongolia have unique situation: more than three million people, ranked the 19th largest area in the world, rich in natural resources, weather extremes, landlocked, and solely two neighboring countries. Fatmata (2004), The United Nations Office of the High Representative for the Least Developed Countries, Landlocked Developing Countries and the Small Island Developing States (UN-OHRLLS) (2013), and $\mathrm{Nu}$ (2009) showed that neighbours and trade partners have significant impact on trade and economic growth.

Alicia (2014) published a paper which is named "Transforming Mongolia-Russia-China Relations: The Dushanbe Trilateral Summit”. Apart from this paper, the above-mentioned transport and energy projects clearly indicate that Mongolia is now well positioned in the middle of Chinese and Russian plans to expand their transportation cooperation throughout the Eurasian region. This trend is likely to continue, particularly with the continuing delay on the development of the second phase of the giant Rio Tinto-controlled copper and gold deposit at Oyu Tolgoi. That project has been touted as inextricably linked to Mongolia's economic development.

Apart from this study, the legal and illegal timber trades of Mongolia were discussed by a recently published report World Bank (2012)/WWF Alliance project, according to which forest sector's trade, it seems that there are only two ways for sustaining the illegal timber export: to pay the smallest share of customs tax therefore bribing customs officials or to smuggle the wood as a transit good from Russia to China through Mongolian territory by negotiating with relevant railway officials. Despite the mission of the project that should concentrate on export and re-export of timber, the study has concentrated more on illegal logging and domestic trade. This is due to increasing domestic demand on timber for the last years and high tax on export has negatively influenced illegal logging.

Nationale-Nederlanden and NMB Postbank Group (ING) (2012) summarized that by 2017, Mongolia will mainly import road vehicles and transport equipment, industrial machinery, and textiles (including fibers, yarn, and products), which together account for 57\% of total imports of Mongolia. Similarly, Mongolia's exports will mainly consist of ores and metals, fuels, and textiles (including fibers, yarn, and products). By 2017, Mongolia will mainly import products from China, Russia, and South Korea, which together account for $82 \%$ of total imports of Mongolia. Mongolia's main export markets will be China, Russia, and Italy.

According to CCPIT (2010), on August 19, the 16th China, Russia, and Mongolia Commercial Chamber Joint Forum, Petrov pointed out that there were still some problems to be addressed. First, Russia was still lacking the relevant laws to regulate the border trade; second, the transportation and logistics were still undeveloped and regulation of customs needs to be improved. 
According to, apart from this paper, Wacaster (2012), Mongolia faces challenges to develop the mining sector responsibly, not only in terms of the environment and industry practices, but also economically in order to avoid a widening trade deficit and inflation that could be the result of rapid economic growth associated with the mining sector.

By following Insight Alpha (n.d.) overview, over the last a few years, the construction industry in Mongolia has grown rapidly and the demand for construction materials is increasing significantly. The introduction of stricter construction standards for buildings and structures has led to an increase in the demand for high performance, inexpensive construction material, satisfying all functional, economic, and ecological requirements.

Tumurtogoo (2009) put forward the following recommendations: (1) To intensify and integrate crop and livestock production; (2) to provide favorable condition for crop planting and animal husbandry; (3) to enhance the labor force; (4) to improve agricultural machinery; (5) to enhance soil fertility; and (6) to use wise managements and strategies.

Asian Development Bank (ADB) (2008) studied that the transport and trade facilitation sectors have witnessed a slowdown in terms of policy development, as well as in the translation of policy into action. Apart from this report, policy-level lessons included: (1) The need to assimilate potential future growth in the respective strategies of the Government and ADB; (2) the need for consistent policy dialogue to draft and implement a transport sector policy, reliable road maintenance regime, and institutional strengthening policy; and (3) government ownership for making and sustaining institutional changes in the country requires champions and coherent support in the country.

Susan (2014) studied that The Soviet Union partnered with Mongolia to build the country's main rail line, a single track running from the Russian border in the north to the Chinese border in the south. The two countries (Mongolia and Russia) partnered, too, to develop the Erdenet copper and molybdenum mine, which opened in 1978 and was until recently Mongolia's top export earner. Mongolia's foreign policy documents commit it to "balanced" relations with both Russia and China, but it is China that has become Mongolia's economic lifeline. China is by far Mongolia's largest trading partner, with nearly 90\% of Mongolian exports destined for China. China is also Mongolia's largest source of foreign investment.

\section{Research Methods}

The representative domain for this study is Mongolian foreign trade chosen per neighbor countries as prescribed by the categorization "China and Russia”. The study used a total of 14 years' data between 2000 and 2013 for a grouping data of China and Russia. The data set used for the study ranges from the period 2000 to 2013 and most required data are extracted from the obtained from National Statistical Office of Mongolia (n.d.) and Mongolian Customs (n.d.).

This paper aims at empirically investigating the causality between trade policy and openness of Mongolia estimated to impact China and Russia trade flows, and it is being done successfully in Mongolian economy.

To achieve this aim, firstly, 14 years' (2000-2013) data of Mongolian imports and exports were collected and went through principal component analysis (PCA) for grouping various trades with China and Russia. A total of 1,442 observations except missing data were classified by PCA, which produced 530 and 912 observations of main export and import goods with China and Russia, respectively. Separating to estimate, Mongolian mainly goods traded the amount volume for export and import to China and Russia and aimed to 
show China or Russia is main export and import country of Mongolia and what products accounted high percent of Mongolia are being exported and imported on bilateral trade with China and Russia. All variables are measured by dollar and were measured exchange rate of MNT to USD based on a database of Central Bank of Mongolia (n.d.). In this study, linear regression is conducted by using PCA and empirical evidence for the Statistical Package for the Social Sciences (SPSS).

According to the Mongolian Customs dynamic statistics, main export commodities of Mongolia have included meat, raw hides and leathers, wool, cashmere, and mining products and main import goods have included the petroleum, food preparation products, vegetables, wine, beer food commodities, fruits, household materials, motor cars, and other motor vehicles for the transport persons with foreign countries.

Secondly, the study runs the empirical evidence that is using seven variables by regression results among Mongolia, China, and Russia during time 2000-2013.

The hypothesis of trade policy and openness is tested using two different dependent variables: total trade and trade openness presented with China and Russia. Moreover, according to, apart from chapter 23 of book, Alberto, Enrico, and Romain (2005) used two dependent variables in the empirical evidence. The explanatory variables included gross domestic product (GDP), population, trade openness, foreign direct investment (FDI), export and import tax revenue, and total trade with China and Russia. Data regarding export and import tariff revenue, total trade with China and Russia, and population were obtained from National Statistical Office of Mongolia (n.d.). Data on FDI were acquired from US Embassy Ulaanbaatar of Mongolia (2014), and measured for each partner country. Data on GDP were acquired from World Bank database. Trade openness has commonly been used with a proxy of trade to GDP ratio through previous literature. The study used trade openness (Import + Export/GDP) as a proxy in this study of China and Russia. The total trade was calculated as a sum of Mongolia's total exports and imports with its partners, China and Russia. The first column in Table 3 presents Mongolia's estimated total trade based on the empirical analysis. The second column reveals the measurement of another dependent variable, i.e., the openness with the two partner countries.

Finally, the study focused on the forecasts from 2016 to 2018 to examine Mongolia's trade flows with China and Russia using OLS method and ARMA terms based for each month of year (2011-2014).

For forecasting the bilateral trade between Mongolia and the two countries, this paper compared the predicted values from the model with the actual data over the "historical" period and the short term period (from January 2011 to December 2014). Dynamic statistics is used to demonstrate the bilateral trade data over the time periods. Data were collected from the Mongolian Customs on the total trade with China and Russia (Export + Import) and the 2016-2018 trade forecasts were estimated by OLS for the eviews.

\section{Research Results}

\section{Principal Component Analysis}

PCA is normally used as a technique of variable reduction or for the discovery of the structure of relationship among variables included. The information available in a group of variables is summed up by a number of mutually independent principal components. Each principal component is essentially the weighted average of the underlying variables. The first principal component usually has the maximum variance for any of the combination (William, Emmanuel, \& Abass, 2013). 
Table 1

Total Variance Explained

\begin{tabular}{|c|c|c|c|c|c|c|c|c|c|}
\hline \multirow[b]{2}{*}{ Component } & \multicolumn{3}{|c|}{ Initial eigenvalues } & \multicolumn{3}{|c|}{ Extraction sums of squared loadings } & \multicolumn{3}{|c|}{ Rotation sums of squared loadings } \\
\hline & Total & $\begin{array}{l}\% \text { of } \\
\text { variance }\end{array}$ & $\begin{array}{l}\text { Cumulative } \\
\%\end{array}$ & Total & $\begin{array}{l}\% \text { of } \\
\text { variance }\end{array}$ & $\begin{array}{l}\text { Cumulative } \\
\%\end{array}$ & Total & $\begin{array}{l}\% \text { of } \\
\text { variance }\end{array}$ & $\begin{array}{l}\text { Cumulative } \\
\%\end{array}$ \\
\hline 1 & 5.963 & 42.595 & 42.595 & 5.963 & 42.595 & 42.595 & 4.746 & 33.900 & 33.900 \\
\hline 2 & 2.479 & 17.708 & 60.302 & 2.479 & 17.708 & 60.302 & 2.655 & 18.965 & 52.864 \\
\hline 3 & 1.558 & 11.128 & 71.431 & 1.558 & 11.128 & 71.431 & 2.011 & 14.364 & 67.228 \\
\hline 4 & 1.297 & 9.266 & 80.697 & 1.297 & 9.266 & 80.697 & 1.831 & 13.082 & 80.310 \\
\hline 5 & 1.009 & 7.208 & 87.905 & 1.009 & 7.208 & 87.905 & 1.063 & 7.594 & 87.905 \\
\hline 6 & 0.678 & 4.845 & 92.749 & & & & & & \\
\hline 7 & 0.442 & 3.159 & 95.909 & & & & & & \\
\hline 8 & 0.314 & 2.246 & 98.155 & & & & & & \\
\hline 9 & 0.169 & 1.211 & 99.366 & & & & & & \\
\hline 10 & 0.075 & 0.537 & 99.903 & & & & & & \\
\hline 11 & 0.012 & 0.089 & 99.991 & & & & & & \\
\hline 12 & 0.001 & 0.008 & 100.000 & & & & & & \\
\hline 13 & $5.972 \mathrm{E}-5$ & 0.000 & 100.000 & & & & & & \\
\hline 14 & $2.316 \mathrm{E}-16$ & $1.654 \mathrm{E}-15$ & 100.000 & & & & & & \\
\hline
\end{tabular}

Note. Extraction method: Principal component analysis.

Table 2

Component Analysis for Volume Amount of Main Trading Products of Mongolia

\begin{tabular}{|c|c|c|c|c|c|c|}
\hline & & Compo & & & & \\
\hline $\begin{array}{l}\text { Foreign trade } \\
\text { of Mongolia }\end{array}$ & Country/Main goods of trade & 1 & 2 & 3 & 4 & 5 \\
\hline \multirow{8}{*}{ Export } & China/Mining & 0.955 & -0.148 & 0.156 & -0.142 & 0.014 \\
\hline & China/Wool and cashmere goods & 0.922 & -0.062 & -0.127 & 0.066 & 0.277 \\
\hline & Russia/Mining goods & 0.883 & 0.023 & 0.413 & 0.062 & -0.065 \\
\hline & China/Raw and leathers goods & 0.069 & 0.673 & 0.077 & -0.566 & -0.272 \\
\hline & Russia/Wool cashmere goods & -0.293 & -0.631 & 0.161 & 0.55 & 0.122 \\
\hline & Russia/Meat goods & 0 & 0.614 & 0.318 & 0.509 & 0.17 \\
\hline & China/Meat goods & 0.573 & -0.33 & -0.623 & -0.012 & -0.061 \\
\hline & Russia/Raw and leather goods & -0.162 & 0.075 & -0.057 & -0.409 & 0.882 \\
\hline \multirow{6}{*}{ Import } & Russia/Petroleum goods & 0.971 & -0.082 & 0.105 & -0.095 & 0.04 \\
\hline & China/Motor cars & 0.818 & 0.041 & 0.433 & -0.064 & -0.059 \\
\hline & Russia/Food goods & 0.772 & 0.343 & -0.209 & 0.312 & 0.054 \\
\hline & Russia/Motor cars & 0.463 & -0.75 & 0.316 & -0.194 & -0.008 \\
\hline & China/Food goods & 0.391 & 0.648 & -0.022 & 0.252 & 0.116 \\
\hline & China/Petroleum & 0.634 & 0.039 & -0.693 & 0.089 & -0.084 \\
\hline
\end{tabular}

PCA analysis models reported with $87 \%$ of all variables (Table 1). In the most ideal situation, analyzing $100 \%$ of the variables would provide complete and accurate findings; however, this is generally not always possible. Moreover, most of the research in this area is reported by analyzing $60 \%$ to $70 \%$ of the variables. As shown by Rotation Component Matrix, the first component is higher than others and sorted by size (Table 2). This volume amount varies from country to country. Regarding export of Mongolia, the lowest value of the first component is -0.162 in the case of Russia (raw and leather goods) and the highest of China (mining 
products), that is, 0.955. Regarding import of Mongolia with China and Russia, the lowest value of the first component is 0.634 in the case of China (petroleum) and the highest of Russia (petroleum products), that is, 0.971 .

\section{Empirical Results}

In this section, the study reviews the empirical evidence whether trade openness can be considered as a main determinant of economic growth.

OLS regression results for the period of 2000-2013 are presented in Table 3. In following Table 3, the empirical results of each country (China and Russia) are reported.

Table 3

Empirical Results

\begin{tabular}{|c|c|c|c|c|}
\hline \multirow[b]{2}{*}{ Countries: } & \multicolumn{2}{|c|}{ Total trade } & \multicolumn{2}{|c|}{ Trade openness } \\
\hline & China & Russia & China & Russia \\
\hline \multirow{2}{*}{ Import tax } & -18.5 & -7.3 & -3.016 & -4.469 \\
\hline & $0.009 * * *$ & $0.10 *$ & $0.049 * *$ & 0.426 \\
\hline \multirow{2}{*}{ Export tax } & -291.37 & -109.57 & 5.45 & 6.57 \\
\hline & $0.029 * *$ & 0.241 & 0.233 & 0.972 \\
\hline \multirow{2}{*}{ Trade openness } & 2.8 & 8.119 & & \\
\hline & $.006 * * *$ & $0.000 * * *$ & & \\
\hline \multirow{2}{*}{ Population } & $-3,942.88$ & $1,413.2$ & 0.001 & 0.000 \\
\hline & $0.001^{* * *}$ & $0.057 *$ & $0.055^{*}$ & $0.036^{* *}$ \\
\hline \multirow{2}{*}{ FDI } & 1.262 & 0.59 & 1.04 & -1.597 \\
\hline & $0.000 * * *$ & 0.455 & $0.097^{*}$ & 0.374 \\
\hline \multirow{2}{*}{ Total trade } & & & 5.55 & 9.35 \\
\hline & & & $0.048 * *$ & $0.025^{* *}$ \\
\hline \multirow{2}{*}{ GDP } & 0.82 & 0.2 & & \\
\hline & $0.000 * * *$ & $0.005^{* * *}$ & & \\
\hline$R^{2}$ & 0.999 & 0.992 & 0.894 & 0.783 \\
\hline Adjusted $R^{2}$ & 0.998 & 0.985 & 0.828 & 0.647 \\
\hline Durbin Watson & 2.767 & 1.759 & 1.127 & 1.182 \\
\hline
\end{tabular}

Notes. Significance level as $* 10 \%$, **5\%, and $* * * 1 \%$.

The estimation results of trade openness and trade policy among Mongolian foreign trade and China and Russia (Table 3 ), have less ( $p>0.00000)$ probability value than 0.05 , which confirms the significance of this paper's model. The estimated value of adjusted $R$-squared (0.647-0.998) was found to be under good range when compared to $R$-squared, hence it proves that the model successfully accounts for all of the variation. Trade openness and trade policy force were found to make a strong impact on neighbour countries' trade, China and Russia.

Trade with China. Trade openness, foreign direct investment (FDI), and gross domestic product (GDP) in Mongolia were significant at $1 \%$ level and had a positive impact on bilateral trade between Mongolia and China. Mongolian import tax, export tax, and population variables are statistically significant with the expected negative sign on total trade flows. For population, FDI and total trade's coefficient posed a significantly positive impact on trade openness of China, conversely, import tax negatively impacted trade openness. Export tax has no impact on trade openness (statistically insignificant). 
Trade with Russia. Trade openness, population, and GDP in Mongolia were significant and had a positive impact on bilateral trade between Mongolia and Russia. Mongolian import tax variable is statistically significant with the expected negative sign on total trade flows. Population and total trade coefficient posed a significantly positive impact on trade openness of Russia, conversely, import tax has no impact on trade openness. Export tax and FDI have no impact on trade openness and total trade (statistically insignificant).

\section{In Forecasting Trade With China and Russia}

The estimated value of adjusted $R^{2}$ is 0.70 and 0.56 , which shows the goodness of this paper's model. The $p$-value is 0.000 which is less than 0.05 , which shows the significance of this paper's model. Bias proportion is shown to be small which suggests that the forecast is reliable. However, the results of variance and covariance proportion are showed not good (Table 4).

Table 4

The Results of Least Squares

\begin{tabular}{|c|c|c|c|c|}
\hline \multicolumn{2}{|c|}{ China } & \multicolumn{3}{|c|}{ Russia } \\
\hline Variable & Coefficient & Prob. & Coefficient & Prob. \\
\hline $\mathrm{C}$ & $328,209.4$ & 0.0000 & $183,240.5$ & 0.0000 \\
\hline @TREND & 506.8873 & 0.7682 & -787.9374 & 0.0833 \\
\hline$@$ MONTH = 2 & $-42,883.17$ & 0.4742 & $-14,520.71$ & 0.4134 \\
\hline$@$ MONTH = 3 & $100,238.1$ & 0.0902 & $-44,980.62$ & 0.0344 \\
\hline @MONTH = 4 & $256,280.3$ & 0.0003 & $-58,575.84$ & 0.0058 \\
\hline$@$ MONTH = 5 & $217,786.7$ & 0.0019 & $-25,910.84$ & 0.1994 \\
\hline$@$ MONTH = 6 & $314,857.5$ & 0.0000 & $-28,997.87$ & 0.1497 \\
\hline @MONTH = 7 & $155,287.7$ & 0.0245 & $-5,884.215$ & 0.7655 \\
\hline @MONTH = 8 & $278,256.7$ & 0.0002 & $14,769.64$ & 0.4547 \\
\hline @MONTH = 9 & $248,770.4$ & 0.0006 & -573.6371 & 0.9767 \\
\hline @MONTH = 10 & $156,353.4$ & 0.0192 & $-9,557.601$ & 0.6238 \\
\hline @MONTH = 11 & $211,790.0$ & 0.0011 & $-24,149.64$ & 0.2042 \\
\hline @MONTH = 12 & $210,371.4$ & 0.0008 & $-21,458.75$ & 0.1828 \\
\hline AR (1) & 0.274590 & 0.1304 & 0.354937 & 0.0557 \\
\hline AR (2) & 0.175525 & 0.3363 & -0.041083 & 0.8086 \\
\hline$R$-squared & 0.701055 & & & 0.539198 \\
\hline Adjusted $R$-squared & 0.566047 & & & 0.331094 \\
\hline Prob. (F-statistic) & 0.000066 & & & 0.013382 \\
\hline
\end{tabular}

Focusing on the monthly trades data (Table 5, Figures 1 and 2), it was seen that the bilateral trade is the highest in the month of June and the lowest in the winter months. It is anticipated that these strong rates between Mongolia and the two countries will significantly drive the growth in the tertiary enrollment rates within each of these countries over the next decade. From the ARMA results, it can be seen that China is expected to have more growth from bilateral trade and by the end of 2018 as compared to Russia. Mongolia's bilateral trade with China forecasted amounts to \$19,551,175 thousand and the bilateral trade forecasted with Russia amounts to $\$ 3,738,794$ thousand for the 2016-2018. Thus, it can be implied that the trade flows in the future may experience continuous increased growth without any major fluctuations. Since Russia and Mongolia have signed an agreement on visa free travels in 2014 for their citizens to stay between the two countries for 30 days in a row, there has been a boom in the bilateral trade between the two nations. In 2015 and 2016, this visa condition had a significant impact, and which is positive for the future of bilateral trades between Russia and 
Mongolia. Since new visa rules between Russia and Mongolia are to follow, the bilateral trade between the two countries may be higher than $\$ 3,738,794$ thousand for the 2016-2018 period.

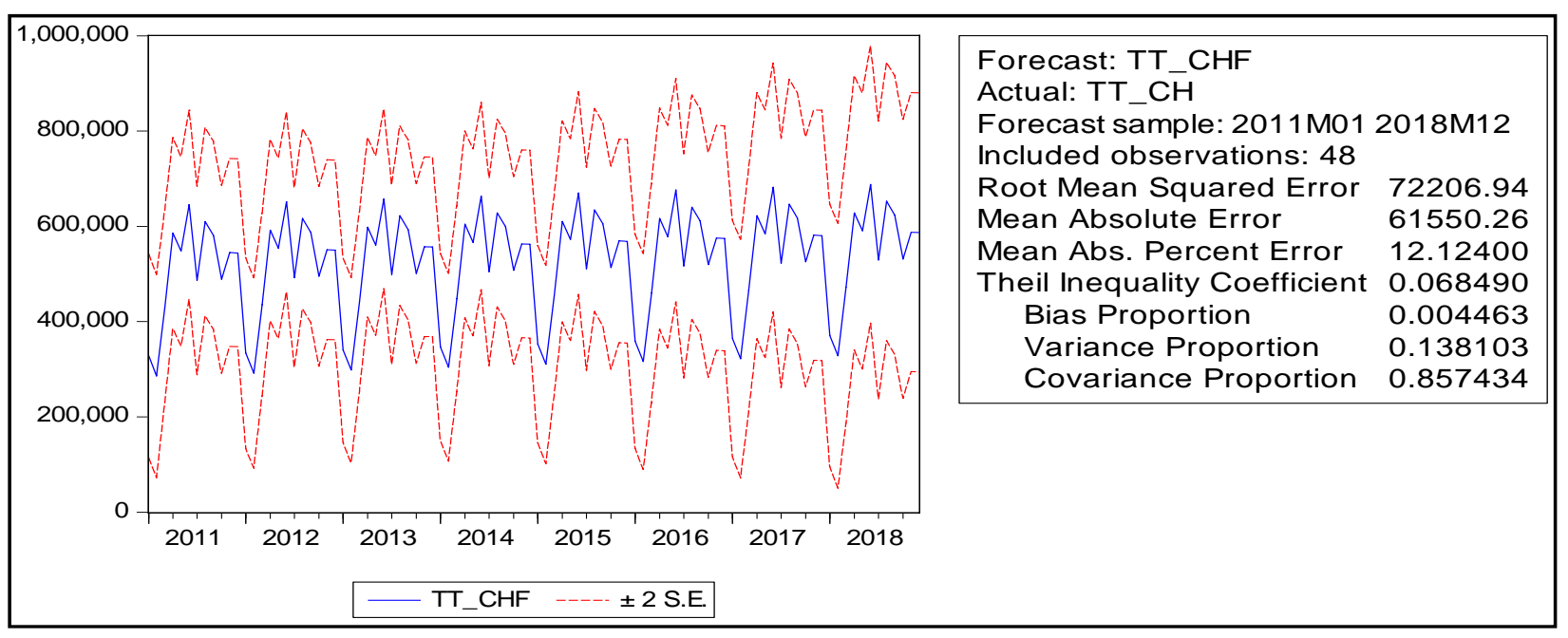

Figure 1. The dynamic statistics_-Trade flow growth with China (2011-2018).

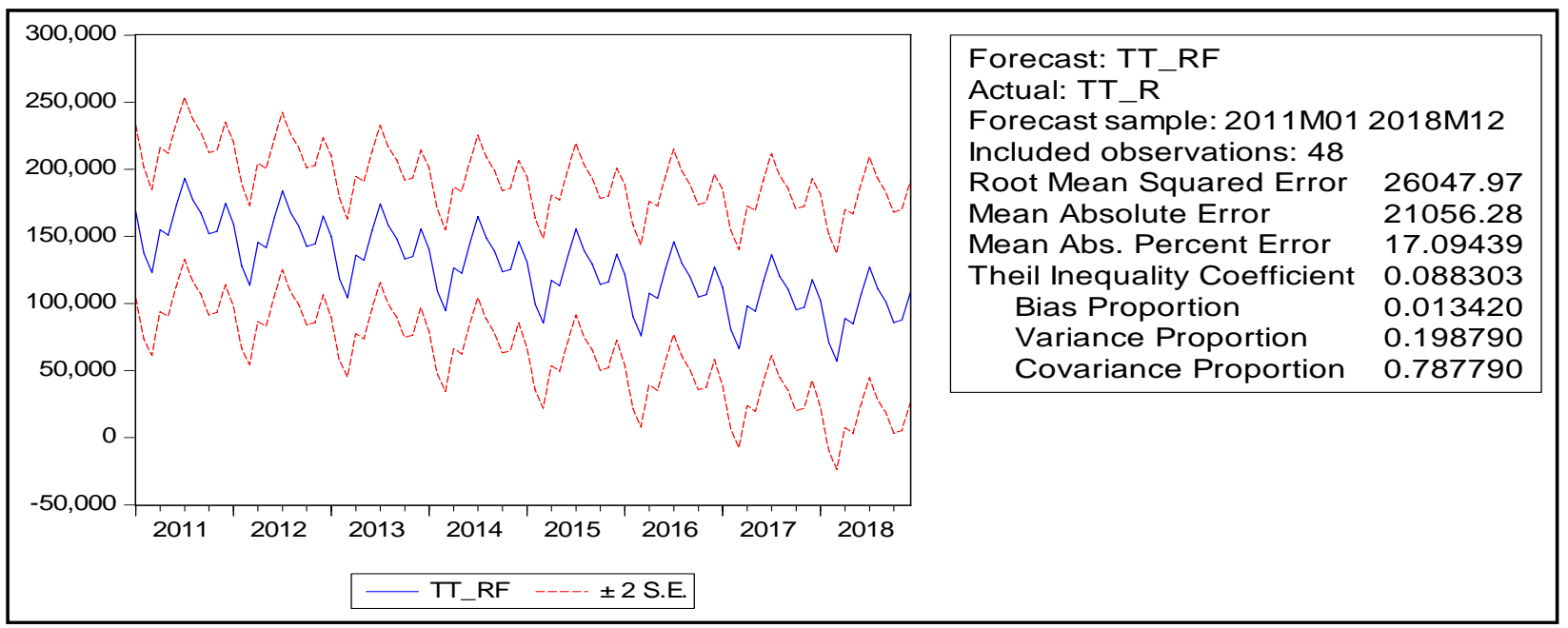

Figure 2. The dynamic statistics-Trade flow growth with Russia (2011-2018). Source: Estimated by authors from data of Mongolian Customs (Figures 1 and 2).

\section{Discussion (Mongolian Trade Policy and Overview Trade With China and Russia)}

\section{Mongolian Trade Policy}

The function of trade policy is being implemented and made by some private sectors' agency, Mongolian Chamber of Commerce and Industry with Government.

Mongolia promoted open trade, supported foreign direct investment, and liberalized foreign trade policy (The State Great Hural (Parliament) of Mongolia, 2010; World Trade Organization, 2014).

According to The State Great Hural (Parliament) of Mongolia (2011), primarily, it was seen that Mongolian trade policy was activated in various ways to increase the exports, which finally can support the overall economy of the country. Living standards were also raised by creating more jobs, concentrating on manufacturing industry such as mining, transportation, tourism, infrastructure, agricultural, energy industry, 
free trade zones, and service sectors. Briefly speaking, the aim of Mongolian trade policy is to move toward increase by export and active trade policy through supporting economic growth, standards of living, and scheme aimed at creating employment, assist on the manufacturing industry, such as mining, transportation, tourism, infrastructure, agricultural, energy industry, free trade zones, service sectors, and all sectors. In particular, Mongolia has been realized in an export structure to increase net value added goods, improve the quality and amount with technical innovation of international standards and high technology exports of wool, cashmere, mining, agriculture, and other domestic products in the world market. Moreover, Mongolian government has realized exemption from tax and financial leverage on main sectors' some commodities to producers.

Mongolia chooses to develop a democratic society with market economy and since 1990, it has been striving after this goal. Within the framework of this objective, the pursuance of a policy to develop free trade and economic relations has resulted in the stabilization of a macro economy (World Trade Organization, 2005).

Mongolian trade policy can be represented by the following sets of general policies by brief background (Figure 3).

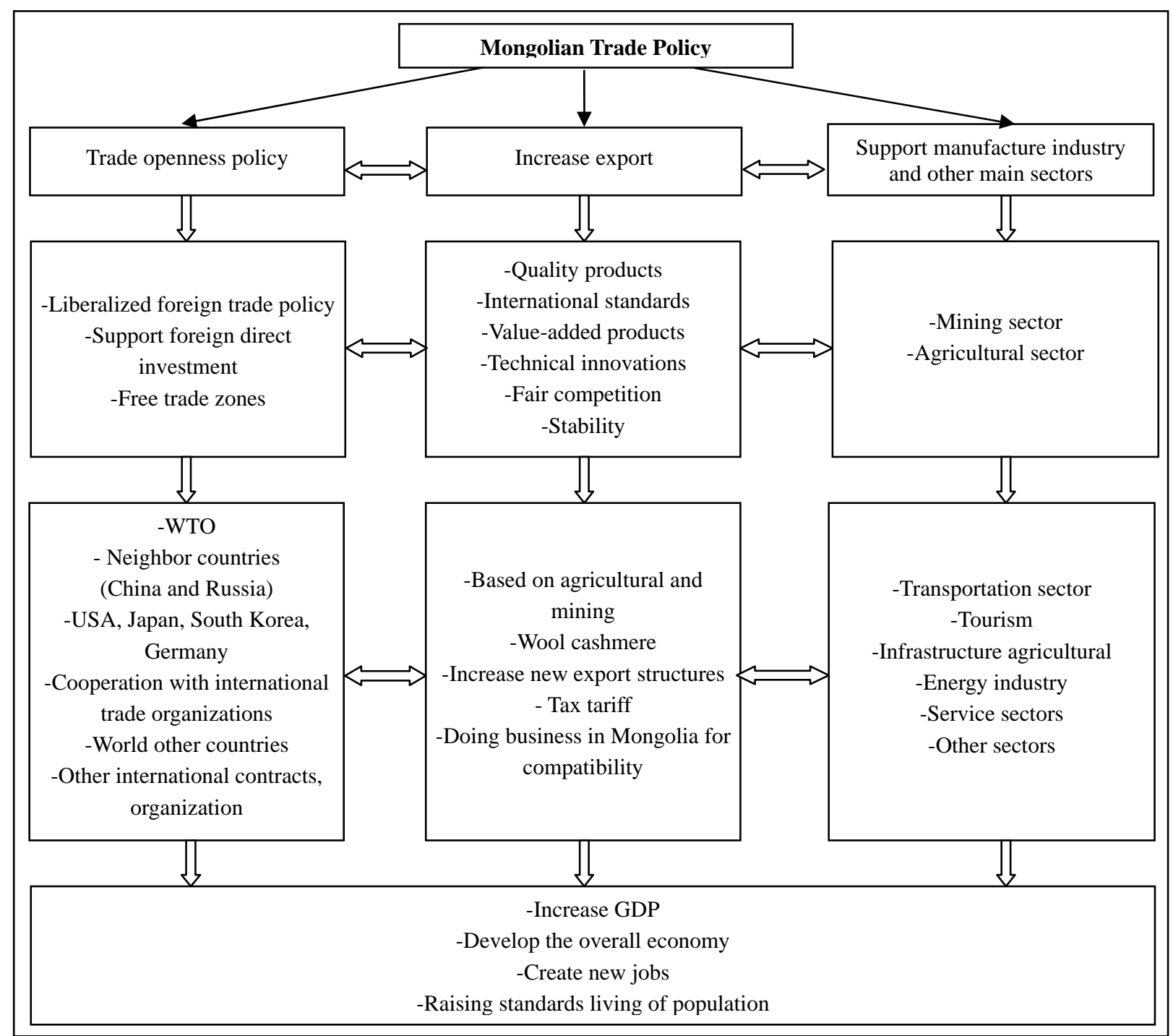

Figure 3. Mongolian trade policy. Source: Figured by authors. 


\section{Overview Trade With China and Russia}

China and Russia are the largest trading countries of Mongolia. The bilateral trade among China-Mongolia-Russia's values is being increased by year to year.

According to the data of National Statistical Office of Mongolia (n.d.), total volume of exports and imports approached \$4,269.1 and \$6,357.8 million, respectively (Figures 4 and 5). China reserved most of total export, amounted \$274.3 million, and reached to about 51\% in year 2000 while amounted \$3,706.3 million and reached $86 \%$ by the year 2013. The export to Russia amounted $\$ 45.14$ million and accounted $8.4 \%$ in year 2000 while amounted $\$ 61.8$ million and reached 1.5\% by the year 2013 in total export of Mongolia.

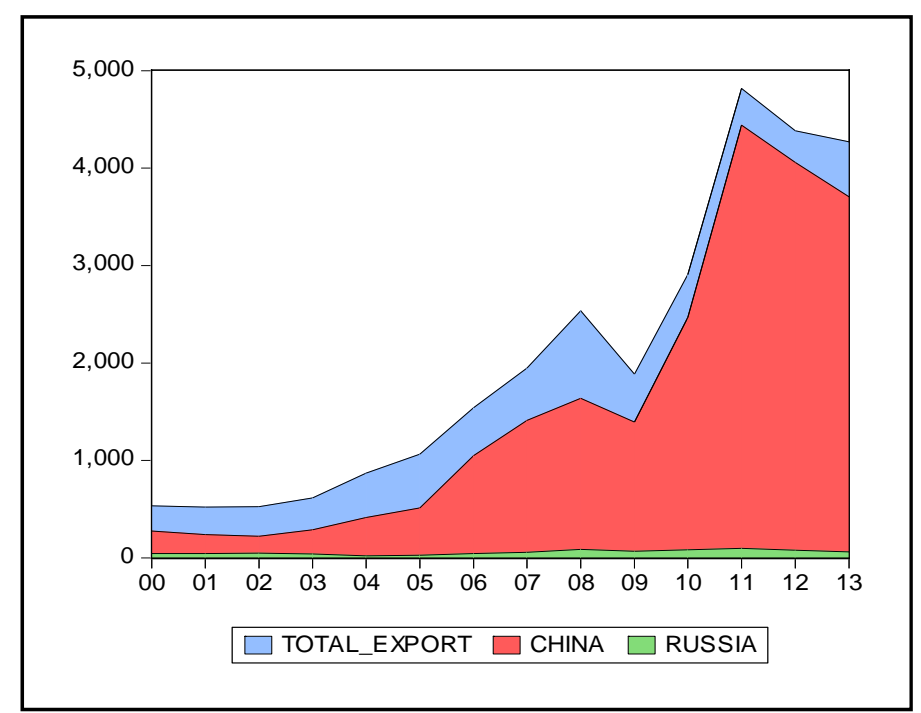

Figure 4. Mongolian total export and export with China and Russia.

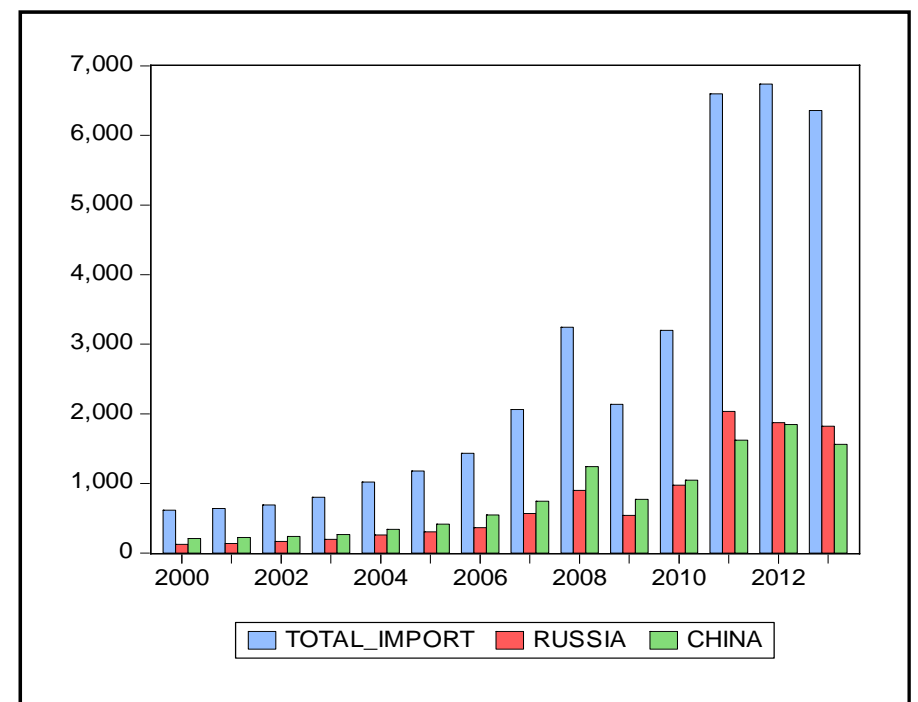

Figure 5. Mongolian total import and import with China and Russia. Source: Data from National Statistical Office of Mongolia (n.d.).

According to 14 years' (2000-2013) statistics, the import from Russia accounted about 33\% and China accounted about $26 \%$ in total import of Mongolia. 


\section{Mongolian Total Exports and Import, Shares Amount of China and Russia (mln USD)}

A recent report of Mongolian Customs represents Chinese and Russian goods shares in main export and import structure of Mongolia with main detailed goods from years 2000-2013 (Table 5).

Table 5

China and Russia Goods Shares in Main Total Export Structure of Mongolia With Main Detailed Goods During in Time 2000-2013, Presented by Value and Share Percent in Groups, Respectively

\begin{tabular}{|c|c|c|c|c|c|c|}
\hline & \multirow{2}{*}{$\begin{array}{l}\text { Categories of } \\
\text { goods of main } \\
\text { commodities }\end{array}$} & \multirow[b]{2}{*}{$\begin{array}{l}\text { Detailed } \\
\text { commodities }\end{array}$} & \multicolumn{2}{|c|}{ China } & \multicolumn{2}{|c|}{ Russia } \\
\hline & & & $\begin{array}{l}\text { Value } \\
\text { (thous. USD) }\end{array}$ & $\begin{array}{l}\text { Shares \% in } \\
\text { categories } \\
(2000-2013)\end{array}$ & $\begin{array}{l}\text { Value } \\
\text { (thous. USD) }\end{array}$ & $\begin{array}{l}\text { Shares \% in } \\
\text { categories } \\
(2000-2013)\end{array}$ \\
\hline \multirow{22}{*}{ Export } & \multirow{4}{*}{ Meats } & Total amounts & $10,657.74$ & 4.13 & $210,924.64$ & 81.75 \\
\hline & & Frozen meat of beef & 93.032 & 0.07 & $115,358.08$ & 96.22 \\
\hline & & Fresh or frozen meat of sheep and goats & $1,367.67$ & 4.19 & 617.36 & 1.89 \\
\hline & & Meat of horse & 9,197.03 & 8.72 & $94,949.19$ & 90.05 \\
\hline & \multirow{4}{*}{$\begin{array}{l}\text { Raw hides } \\
\text { and leathers }\end{array}$} & Total amounts & 392,997.9 & 89.5 & 80.4 & 0.02 \\
\hline & & Leather of beef or horse & $64,506.67$ & 74.66 & 0 & 0 \\
\hline & & Sheep or lamb skin leather & $274,613.28$ & 96.28 & 0 & 0 \\
\hline & & Goat or kid skin leather & $53,877.96$ & 80.02 & 0 & 0 \\
\hline & \multirow{4}{*}{$\begin{array}{l}\text { Wool and } \\
\text { cashmere }\end{array}$} & Total amounts & $1,238,203.73$ & 69.62 & 0 & 0 \\
\hline & & Cashmere, not washed & $26,047.88$ & 97.41 & 0 & 0 \\
\hline & & Cashmere, washed & $884,918.50$ & 99.77 & 0 & 0 \\
\hline & & Cashmere, combed & $327,050.70$ & 38.20 & 0 & 0 \\
\hline & \multirow{10}{*}{$\begin{array}{l}\text { Mining } \\
\text { products }\end{array}$} & Total amounts & $19,503,770.67$ & 83.67 & $466,622.39$ & 2.00 \\
\hline & & $\begin{array}{l}\text { Gold, unwrought or in } \\
\text { semi-manufactured forms }\end{array}$ & $26,273.32$ & 0.88 & $5,865.37$ & 0.20 \\
\hline & & Tungsten ores and concentrates & $16,049.41$ & 68.70 & $2,150.67$ & 9.21 \\
\hline & & Fluorspar & $147,626.00$ & 22.27 & $422,552.48$ & 63.75 \\
\hline & & Iron ores and concentrates & $2,094,625.70$ & 99.91 & 35.34 & 0.002 \\
\hline & & Zinc ores and concentrates & $1,078,957.21$ & 99.75 & $2,670.84$ & 0.25 \\
\hline & & Crude oil & $1,576,497.41$ & 99.99 & 0.06 & 0.00 \\
\hline & & Copper ores and concentrates & $7,486,683.02$ & 99.37 & $28,881.37$ & 0.38 \\
\hline & & Molybdenum ores and concentrates & $272,526.81$ & 51.85 & $1,131.53$ & 0.22 \\
\hline & & Coal & $6,804,531.78$ & 99.54 & 3,334.73 & 0.05 \\
\hline \multirow{7}{*}{ Import } & \multirow{3}{*}{$\begin{array}{l}\text { Petroleum } \\
\text { products }\end{array}$} & Total amounts & $226,372.57$ & 3.29 & $6,877,974.39$ & 90.42 \\
\hline & & Diesel fuel & $91,956.97$ & 1.99 & $4,331,716.67$ & 93.63 \\
\hline & & Gasoline & $134,415.60$ & 4.51 & $2,546,257.72$ & 85.42 \\
\hline & Foods & $\begin{array}{l}\text { Food preparation products, vegetables, } \\
\text { wine, beer food commodities, and fruits }\end{array}$ & $352,680.53$ & 20.27 & $497,940.69$ & 28.62 \\
\hline & $\begin{array}{l}\text { Construction } \\
\text { materials }\end{array}$ & Construction materials* & $778,181,489.65$ & 69.91 & $222,946,304.86$ & 20.03 \\
\hline & $\begin{array}{l}\text { Household } \\
\text { materials }\end{array}$ & Household materials** & $2,212.10$ & 1.48 & $34,893.40$ & 23.38 \\
\hline & Cars & $\begin{array}{l}\text { Motor cars and other motor vehicles for } \\
\text { the transport persons and goods }\end{array}$ & $984,525.70$ & 18.78 & $147,286.90$ & 2.81 \\
\hline
\end{tabular}

Source: Estimated by authors from data of Mongolian Customs (/http://www.customs.gov.mn/statistics/). Notes. *presented since 2008 and **presented since 2001. 
Main exports of Mongolia include mining products to China that amounted \$19,503,770.67 thousand and reached about $83.67 \%$ in total mining exports from 2000 to 2013. Other than the mining products, Mongolian largest exports to China are leather goods (raw leather and finished leather products) and wool (including cashmere), which accounted to $89.5 \%$ and $69.62 \%$ respectively. Although China's shares percent is not as high level as exports of meats during 2000-2013 that reached about $4.13 \%$ in export meats.

Mongolia mainly exported a large amount of meats (sheep, horse, goats, and beef) to Russia, which amounted \$210,924.64 thousand and reached 81.75\% in total meats exports from 2000 to 2013. Although Russia's shares percent is a small level as in exports of raw hides and finished leather products, wool and cashmere, leather products, and mining products during 2000-2013.

Regarding imports, mainly the petroleum products are imported from Russia that amounted \$6,877,974.39 thousand and reached about $90.42 \%$ in imports of petroleum goods (2000-2013). Shown from Table 5, food preparation products, vegetables, wine, beer food commodities and fruits, construction materials, and household materials from Russia accounted about 20-28\% (2000-2013). In addition, Russia's shares percent is not a big percent as in import of motor cars and other motor vehicles for the transport persons and goods that reached about $2.81 \%$ in total cars imports (2000-2013).

Mongolia mainly imported construction materials from China amounted \$778,181,489.65 thousand and accounted about $69.91 \%$ in total construction materials imports (2008-2013). Food preparation products, vegetables, wine, beer food commodities and fruits, motor cars, and other motor vehicles for the transport persons and goods accounted about $20.27 \%$ and $18.78 \%$, respectively in sample times. However, China shares not high percent for petroleum and household products that accounted about $3.29 \%$ and $1.48 \%$ in imports of petroleum and household products (2000-2013).

Mongolia's thriving mining industry has created high demands for construction materials and automobiles. Subsequently, this has generated strong impacts on the import of such goods.

Mongolia's imports have exceeded its exports in the last decade. This may be related to the lower manufacturing capacity of the domestic market and subsequently it has had an effect on the direct as well as indirect trade flows.

\section{Conclusion}

The result led to concluding that China and Russia have positive and significant influence on Mongolian foreign trade. Bilateral trade among China-Mongolia-Russia is being expanded with each year. Mongolian trade and openness policy significantly impacted the exports and imports of China and Russia. China is the main partner of exports in mining, wool, and cashmere market, while Russia is the main partner in imports of petroleum and food products with Mongolia. Almost all variables are significant in relation to trade policy, which is an indication that trade policy and openness play an important role in economy. Mongolia-China trade was focused amounted \$19,551,175 thousand and the bilateral trade with Russia amounted \$3,738,794 thousand during three years (2016-2018). Since new visa rules between Russia and Mongolia are to follow, the bilateral trade between the two countries may be higher than $\$ 3,738,794$ thousand for the 2016-2018 period.

As shown by the structure of export and import, goods with China and Russia influenced the mutual trade amount. Moreover, China and Russia traded to continue with Mongolia for goods in long run. China-Mongolia-Russia trade flows will continue to dominate during the forecasted period. 
Based on the results, the following are a few directions to increase further the trade. From the results, the study may summarize some conceptions of Mongolia:

- The government of Mongolia should review open trade policy, as well as a strong check on quantity and quality of export goods.

- Annual review of the tariff should be done. Reduced taxes may have a positive impact on the bilateral trade with China and Russia.

- Mongolian business owners may have hurdles to access Chinese and Russian markets regarding quotas and import tariff.

- Mongolian population is quite small; hence less demand and supply are very common issues.

- Both China and Russia can increase FDI to Mongolia to a higher extent that positively influences mutual benefit.

The empirical analysis from this study shows the positive and negative factors can influence the trade openness and total trade with China and Russia.

\section{Population}

According to Amjad (n.d.), export and import of goods depend on the size of the countries as well as the supply and demand. Mongolia has a small population that is rising gradually; nevertheless, the increase maybe can not catch rapidly. As follow solutions may:

- Creation of world famous Mongolian brand.

- Development of the tourism and technology sector may increase the number of tourists traveling to Mongolia.

\section{Import and Export Tax}

The governments can receive tax revenues in their exports and imports. Yet, it is important for them to realize how the benefits from the tax revenues can be maximized by allocating them efficiently. Optimal and low tariff may increase the economic growth. It has been seen that export and import taxes have negative impact on bilateral trade with China and Russia (during 2000-2013). As follow solutions may:

- Strong commitments towards developing export and import agreements between the neighboring countries.

- Estimating the optimal tariff on export and import.

- Mongolia should increase its export volume for China and Russia with more high quality goods. Mongolian government needs to facilitate domestic companies in tax policies and transfer of technical innovation of international standards.

\section{Foreign Direct Investment}

As seen from the empirical analysis, the amount of FDI is not enough to sustain international trade and moreover, the investment in fewer sectors may have negative influence on the bilateral trades. As follow solution may:

- Increase in the attraction of FDI to Mongolia, has a positive influence on the total trade and the economy.

\section{Logistics}

Mongolia is a land locked between two big countries, China and Russia; thus it is necessary that more attention should be given to the logistic problems. As follow solutions may: 
- Working more actively together with the neighboring countries including Russia and China and with the international organizations.

- Most of the population and businesses are located in Ulaanbaatar, the capital of Mongolia. There should be more focus on locating businesses in the areas bordering China and Russia to encourage trade.

- Developing and upgrading the railway technology and capacity.

- Developing and investing in airways and road development.

- Encouraging the flow of tax free goods at airports may improve purchase capacity of consumer. The new international airport will have a positive impact on the total trade as well as international trade. According to new Ulaanbaatar international airport/wiki (2016), project is expected to finish in December 2016.

Mongolia has an opportunity to expand its economy by increasing its exports through agriculture, mining, tourism, as well as wool and cashmere goods. Due to neighborhoods, China-Mongolia-Russia trade mutually can benefit from each other, in terms of supply of goods with minimal prices. China-Mongolia-Russia have opportunity to develop more and more mutual economy and mutual ties in all sectors in the future decades.

\section{References}

Alberto, A., Enrico, S., \& Romain, W. (2005). Trade growth and the size of countries. Handbook of Economic Growth, 1 (Part B, Chapter 23).

Alicia, C. (2014). Transforming Mongolia-Russia-China relations: The Dushanbe trilateral summit. The Asia-Pacific Journal, 12(45), 1-8.

Amjad, K. (n.d.). International trade theory and policy [TRIPOD, Lycos. Inc]. Retrieved from http://khan-amjad.tripod.com/

Antoine, C. E. K., \& Andreas, S. (2006). Openness in services trade and economic growth. Economics Letters, 92(2), $277-283$.

Arvind, P., Jagdish, B., \& Srinivasan, T. N. (1998). Think again: International trade (lectures). Cambridge: MIT Press.

Asian Development Bank. (2008). Transport and trade facilitation-Potential for better synergies in Mongolia (SAP: MON 2008-26). Evaluation Study.

CCPIT. (2010). Proceedings from The Sixth China, Russia and Mongolia Commercial Chamber Joint Forum: Commercial Communities in China, Russia and Mongolia for Better Cooperation. New Siberia, Russia.

Central Bank of Mongolia. (n.d.). The statistics of exchange rate 2000-2013 [Data file].

Susan, V. L. (2014). Mongolia: Issues for congress. Congressional Research Service. (Prepared for members committees of congress, R 41867).

Tumurtogoo, E. (2009). Food demand and supply of Mongolia. Mongolian State University of Agriculture. Retrieved from http://www.nodai.ac.jp/cip/iss/english/9th_iss/fullpaper/1-2-4msua-enkhbayar.pdf

Fatmata, L. S. (2004). Conflict in neighbouring (developing) countries: Direct and indirect effects on economic growth. TIGER Working Paper Series, No. 68, Warsaw.

IHS Global Inc. (n.d.). Eviews online tutorials /basic forecasting. Retrieved from http://www.eviews.com/Learning/forecasting.html Nationale-Nederlanden and NMB Postbank Group (ING). (2012). Developments in Global Trade From 1995 to 2017, Mongolia.

Insight Alpha. (n.d.). Industry overview: Mongolia construction industry energy authority of Mongolia. Retrieved from http://insightalpha.com/news_details.php?cid=206\&sid=75\&nid=243\#

International Trade Policy/Baidu. (2012). The international trade policy Baidu. Retrieved from http://wenku.baidu.com/link?url=WZ0eZcubSvhhbVaCjpMg3qIY-aKDGVVwl8Gyjoms6HBT0YLdgAZ850aqYgQKWo0n qWQeajWjIwLd4oVGg1S8RaChQllbyU7cN3F-Ro_oCjy

Ministry of Industry and Trade \& Ministry of Foreign Affairs and Trade in Mongolia United Nations Development Program in Mongolia (UNDP Mongolia). (2008). Trade policy and human development in Mongolia. Ulaanbaatar, Mongolia.

Mongolian Customs. (n.d.). The data of dynamic statistics. Retrieved from http://www.customs.gov.mn/statistics/.

Muhammad, T. M., Irfan, N., \& Sadaf, S. (2014). Impact of trade liberalization on the economy: Cross-country analysis of selected Asian economics. Innovative Systems Design and Engineering, 5(5), 22-30.

Munkh-Erdene, T. E. (2014). Attracting China’s direct investment: The Mongolian perspective (Master dissertation, Donghua University). Dissertation Conclusion, 78-81. 
National Statistical Office of Mongolia. (n.d.). Mongolian statistical data2000-2013. [Data file]. Retrieved from http://1212.mn/ Nayyra, Z., Fu, Q., \& Sundas, R. (2014). Role of foreign direct investment in economic growth of Pakistan. International Journal of Economics and Finance, 6(1), 32-38.

New Ulaanbaatar international airport/wiki. (2016). Retrieved from the new Ulaanbaatar international airport Wiki: https://en.wikipedia.org/wiki/New_Ulaanbaatar_International_Airport

Nu, N. L. (2009). Analysis on international trade of CLM countries. Institute of Developing Economies, IDE Discussing Paper, No. 215. Retrieved from http://ir.ide.go.jp/dspace/bitstream/2344/865/1/215.pdf

Oyunbadam, D., Kishor, S., \& Yapa, M. W. Y. B. (2014). Export performance during economic transition in Mongolia. Economic Analysis and Policy, 44, 442-450.

Robin, B. (2012). An introduction to principal component analysis \& factor analysis (Original version by D. Chris). Retrieved from http://www.doc88.com/p-3897512941820.html

The State Great Hural (Parliament) of Mongolia. (2011). The Contention of foreign affairs of Mongolia (the annex of 10th act of 2011). The state of Great Hural of Mongolia. (Original work published 2011).

The State Great Hural (Parliament) of Mongolia. (2010). Mongolian foreign policy and trade issues, a program of economic and international trade relationship with neighboring for foreign trade (CT-10/302). Ulaanbaatar of Mongolia: Centre of Research. T. Norovdondog, D. Ariunaa, T. Batbayar, and C. Oyunchimeg (Original work published 2010).

Wacaster, S. (2012). The mineral industry of Mongolia (US geological survey minerals yearbook-2010). US Department of the Interior, USA.

The United Nations Office of the High Representative for the Least Developed Countries, Landlocked Developing Countries and the Small Island Developing States (UN-OHRLLS). (2013). Proceedings from Second UN Conference: Report of the Brainstorming Meeting on the Priorities of a New Development Agenda for the Landlocked Developing Countries: Report Mongolia. United Nations, New $\quad$ York. $\quad$ Retrieved from http://www.lldc2conference.org/custom-content/uploads/2013/07/Mongolia-National-report.pdf

US Embassy Ulaanbaatar in Mongolia. (2014). 2014 Mongolian investment climate. Ulaanbaatar, Mongolia.

William, G. C., Emmanuel, A. W., \& Abass, A. (2013). FDI and trade policy openness in Sub-Saharan Africa. MPRA PAper, No. 58074. Retrieved from https://editorialexpress.com/cgi-bin/conference/download.cgi?dbname=CSAE2014\&paper_id=500

World Bank. (2002). A report on legal and illegal timber trade of Mongolia. /WWF Alliance project/. WWF-Mongolia Programme Office.

World Bank. (n.d.). World development indicator. Retrieved from http://www.worldbank.org/en/country/mongolia

World Trade Organization. (2005). Trade policy review report by Mongolia (first report). Geneva.

World Trade Organization. (2014). Trade policy review report by Mongolia (second report). Geneva. 